\title{
RESEARCH PAPER \\ Finishing strategies for steers based on pasture or silage plus grain and time on feed and their effects on beef quality
}

\author{
Rodrigo Morales ${ }^{1}$, Julian Parga ${ }^{1}$, Ignacio Subiabre ${ }^{1}$, and Carolina E. Realini ${ }^{2}$ \\ 'Instituto de Investigaciones Agropecuarias, INIA Remehue, Ruta 5 Norte km 8, Casilla 24-0, Osorno, \\ Chile. \\ ${ }^{2}$ Institut de Recerca i Tecnologia Agroalimentaries (IRTA), Finca Camps i Armet s/n, E-17121, Monells
}

(Girona), Spain.

\begin{abstract}
R. Morales, J. Parga, I. Subiabre, and C.E. Realini. 2015. Finishing strategies for steers based on pasture or silage plus grain and time on feed and their effects on beef quality. Cien. Inv. Agr. 42(1): 5-18. The aims of the present study were to compare the quality of grainfed and pasture-fed beef and to assess the effects of two feeding periods on grain for finishing steers. A group of 75 steers were fed one of 5 finishing diets ( $n=15$ per diet): pasture for $90 \mathrm{~d}$ (P), oat grain plus pasture silage for $35 \mathrm{~d}(\mathrm{SO})$, oat grain plus pasture silage for $75 \mathrm{~d}(\mathrm{LO})$, wheat grain plus pasture silage for $35 \mathrm{~d}(\mathrm{SW})$, and wheat grain plus pasture silage for $75 \mathrm{~d}(\mathrm{LW})$. The physicochemical and sensory attributes and the fatty acid composition of the longissimus lumborum muscle were determined. The beef from pasture-fed animals tended to be tenderer, darker, less red, and with yellower fat than the beef from grain-fed steers. The beef from steers fed wheat plus silage for $75 \mathrm{~d}$ had lower tenderness scores than beef from steers fed for $35 \mathrm{~d}$ on grain plus silage. The beef from pasture-fed steers had higher levels of conjugated linoleic acid $c-9 t-11$ and $n-3$ fatty acids and a lower $n-6: n-3$ fatty acid ratio than the beef from grain-fed steers. The time fed on grain plus silage had a significant effect on the fatty acid composition of the beef from steers fed wheat, but no similar effect was observed in beef from steers fed oats. However, the $n-6: n-3$ ratio of beef was more favorable when steers were fed grain (wheat or oats) plus silage for $35 \mathrm{~d}$ than for $75 \mathrm{~d}$.
\end{abstract}

Key words: Beef quality, CLA, fatty acids, Holstein Friesian steers.

\section{Introduction}

Producers and consumers are both interested in the nutritional quality of beef, because of the added value the producers obtain for their product and because of the desire of consumers to eat healthier food. Research has focused on

Received June 6, 2014. Accepted January 21, 2015. Corresponding author: rmorales@inia.cl improving the nutritional quality of beef with modifications of the animal diet. The beef from animals raised on pasture has lower concentrations of fat and cholesterol and more polyunsaturated fatty acids (PUFAs) than beef from animals raised on feedlots (Schor et al., 2008). Additionally, the beef from animals fed on pasture contains more $n-3$ fatty acids and conjugated linoleic acid (CLA) than beef from feedlot animals because of the high content of linolenic acid $(n-3)$ in 
lipids from pastures (Elgersma et al., 2006). Conjugated linoleic acid (CLA), naturally found in food products from ruminants, is a mixture of positional and geometric isomers of linoleic acid (C18:2 n-6 c-9, $c-12$ ), with two conjugated double bonds at various carbon positions in the fatty acid chain. Dilzer and Park (2012) reported that CLA C18:2 cis-9 trans-11 (rumenic acid) possessed anticarcinogenic and immunostimulant properties, among others.

In recent years, consumers have demanded healthier foods and are willing to pay a premium for products enriched with $n-3$ and/or CLA fatty acids (Realini et al., 2014). Additionally, Chilean consumers have a positive view of animals fed on pasture and raised outdoors (Morales et al., 2013). The majority of the beef production system in the southern regions relies on grazing in temperate pastures. However, pasture production varies considerably throughout the year and growth rates are low in winter and dry summers, with growth rates as low as $20 \mathrm{~g}$ of dry matter ha $\mathrm{d}^{-1}$ in winter months (Teuber, 2009). Thus, grains are used as supplements during the winter to finish steers for the national and international beef markets. In general, the finishing of beef cattle in the southern regions of Chile relies on conserved forage (silage or hay) and supplementation with grains during the winter. Oats and wheat, among other grains, are traditionally used for cattle finishing (Rojas et al., 2011). Additionally, better cattle prices are obtained on the markets in winter than in summer, when pasture production is high and the majority of the animals in the southern regions of Chile are slaughtered.

The concentration of healthy fatty acids is higher in the beef from animals finished on pasture than in the beef from steers finished on grain-based diets. A recent study evaluated the nutritional quality (intramuscular fat, cholesterol content and fatty acid composition) of beef produced in Chile under different production systems that were classified according to the type of finishing diet (Morales et al., 2012). Information on the use of diets of grain plus pasture on beef fatty acid profiles is also available (Klee et al., 2011). Nevertheless, in the cited studies, the quality of beef finished on winter diets, including grains, and using different feeding periods was not considered. Additionally, limited information is available on the length of time to feed cattle on grain for finishing. The aims of the present study were to compare the quality of grain-fed and pasture-fed beef and to assess the effects of two different feeding periods on grain on the finishing of steers.

\section{Materials and methods}

\section{Animals and diets}

A group of 75 Holstein-Friesian steers of similar age (autumn birth, 14 months old) were selected from the animal production unit of the Instituto de Investigaciones Agropecuarias (INIA) Remehue (4031'S; 733의 ; altitude $73 \mathrm{~m}$; annual rainfall $1,300 \mathrm{~mm}$ ) for the present study. The average initial live weight of an animal in the group was $355.9 \pm 55.2 \mathrm{~kg}$, and the steers were maintained with a common feeding system until they reached a target live weight (390-450 kg). The preexperimental phase was conducted for 90 days in the winter months (Preexperimental phase, Figure 1). The animals were then divided according to live weights into five groups of 15 steers each to be finished under the different systems (Experimental phase). The steers were blocked according to live weight within the treatments. The steers with live weights of $450 \mathrm{~kg}$ were assigned to finishing for $35 \mathrm{~d}$ with oat grain (SO) or with wheat grain (SW) plus pasture silage, whereas the rest of the steers were finished for $75 \mathrm{~d}$ with oat grain (LO) or wheat grain (LW) plus pasture silage or only pasture for $90 \mathrm{~d}(\mathrm{P})$. The target live weight at slaughter was approximately 500 $\mathrm{kg}$. All grain treatments were formulated to be approximately protein equivalent and isocaloric, and the grain (wheat or oat) was provided at $1 \%$ of the animal live weight, whereas the pasture 
silage was provided at $2 \%$ of live weight. The diets were adjusted weekly according to the animal live weight. The five treatments were supplemented with a mineral mix. The initial and final live weights, the average daily weight gain and the characteristics of the diet are shown in Figure 1. The pasture was improved grassland with an approximate production of 10 ton dry matter ha ${ }^{-1}$ year ${ }^{-1}$, which was composed primarily of perennial ryegrass (Lolium perenne), brome grasses (Bromus spp.), Yorkshire fog (Holcus lanatus), and white clover (Trifolium repens). The grazing system used for the P-group was strip grazing, which was used during the spring (September-December).
The chemical and fatty acid composition of the feed used in the preexperimental and experimental phases are shown in Table 1. The simulated grazed pasture samples were collected in plastics bags from the allowance pasture strips. All the feed samples were transported refrigerated to the laboratory and were dried for $48 \mathrm{~h}$ at $60{ }^{\circ} \mathrm{C}$ for chemical analyses. The chemical content of the feed samples was analyzed at the INIA Remehue Animal Nutrition and Environment Laboratory in Osorno, Chile. The dry matter, crude protein, ether extract and ash were measured with the methods described by the AOAC (2005). The metabolizable energy and the neutral detergent fiber were determined according to Sadzawka et al. (2007).

Experimental phase

\begin{tabular}{|c|c|c|}
\hline & Treatments & FLW /ADG \\
\hline \multirow{5}{*}{$\begin{array}{l}\text { Group of } 75 \text { steers } \\
\text { Initial Live Weight } \\
(\text { IIW) }=355.8 \pm 55.2 \mathrm{~kg} \\
\text { Pasture }=1.2-5.7 \mathrm{~kg} \text { Dry Matter (DM) } \\
\text { Pasture Silage }=0.8-3.0 \mathrm{~kg} \mathrm{DM} \\
\text { Pasture Hay }=0.2-2.2 \mathrm{kgDM} \\
\text { Average daily gain }(\mathrm{AD} \mathrm{G})=0.6 \mathrm{~kg} \mathrm{~d}^{-1} \\
\text { Period }=90 \mathrm{~d}\end{array}$} & $\begin{array}{l}\text { Short finishing Oats } \\
\text { (SO group) } n=15 \text { steers } \\
\text { ILW }=449.1 \mathrm{~kg} \pm 21.1 \mathrm{~kg} \\
\text { Oats } 1.0 \% \text { of } \mathrm{LW}+\text { pasture silage } \\
(2.0 \% \text { of } \mathrm{LW}) \text { per } 35 \mathrm{~d}\end{array}$ & $\begin{array}{c}485.6 \mathrm{~kg} \pm 30.4 \mathrm{~kg} \\
1.9 \mathrm{~kg} \mathrm{~d}^{-1}\end{array}$ \\
\hline & $\begin{array}{l}\text { Short finishing Wheat } \\
\text { (SW group) } n=15 \text { steers } \\
\text { ILW }=445.9 \mathrm{~kg} \pm 18.1 \mathrm{~kg} \\
\text { Wheat } 1.0 \% \text { of } \mathrm{LW}+\text { pasture silage } \\
(2.0 \% \text { of } \mathrm{LW} \text { ) per } 35 \mathrm{~d}\end{array}$ & $\begin{array}{c}490.4 \mathrm{~kg} \pm 33.4 \mathrm{~kg} \\
1.9 \mathrm{~kg} \mathrm{~d}^{-1}\end{array}$ \\
\hline & $\begin{array}{l}\text { Long finishing Oats } \\
\text { (LOgroup) } n=15 \text { steers } \\
\text { ILW }=393.6 \mathrm{~kg} \pm 37.4 \mathrm{~kg} \\
\text { Oats } 1.0 \% \text { of } \mathrm{LW}+\text { pasture silage } \\
(2.0 \% \text { of } \mathrm{LW} \text { ) per } 75 \mathrm{~d}\end{array}$ & $\begin{array}{c}462.0 \mathrm{~kg} \pm 37.6 \mathrm{~kg} \\
1.5 \mathrm{~kg} \mathrm{~d}^{-1}\end{array}$ \\
\hline & $\begin{array}{l}\text { Long finishing wheat } \\
\text { (LW group) } n=15 \text { steers } \\
\text { ILW }=390.5 \mathrm{~kg} \pm 27.9 \mathrm{~kg} \\
\text { Wheat } 1.0 \% \text { of } L W+\text { pasture silage } \\
(2.0 \% \text { of } L W) \text { per } 75 \mathrm{~d}\end{array}$ & $\begin{array}{c}477.4 \mathrm{~kg} \pm 29.6 \mathrm{~kg} \\
1.6 \mathrm{~kg} \mathrm{~d}^{-1}\end{array}$ \\
\hline & $\begin{array}{l}\text { Pasture finishing } \\
\text { (P group) } n=15 \text { steers } \\
\text { ILW }=384.3 \mathrm{~kg} \pm 20.1 \mathrm{~kg} \\
\text { Only Pasture on grazing } \\
(2.2-2.4 \% \text { of } L W) \text { per } 90 \mathrm{~d}\end{array}$ & $\begin{array}{c}503.3 \mathrm{~kg} \pm 28.4 \mathrm{~kg} \\
1.0 \mathrm{~kg} \mathrm{~d}^{-1}\end{array}$ \\
\hline
\end{tabular}

Figure 1. Initial (ILW) and final live weights (FLW), average daily gain (ADG) and the preexperimental and experimental phase diets for all treatments.

Slaughter and sample procedure

The steers were slaughtered at a commercial meat plant that was licensed for export when the treatment was completed. The average live weight of the steers slaughtered was between
460 and $500 \mathrm{~kg}$. The animals were slaughtered following standard procedures, and the average cold carcass weights were 242.8, 231.7, 247.2, 248.1 and $268.1 \mathrm{~kg}$ for the SO, LO, SW, LW and $\mathrm{P}$ groups, respectively. 
Table 1. Average chemical compositions of the diets in the pre-experimental and experimental phases ( $\mathrm{n}=3$ by feed).

\begin{tabular}{|c|c|c|c|c|c|c|c|}
\hline & \multicolumn{3}{|c|}{ Pre-experimental feed } & \multicolumn{4}{|c|}{ Experimental feed } \\
\hline & Pasture & $\begin{array}{l}\text { Pasture } \\
\text { silage }\end{array}$ & $\begin{array}{c}\text { Pasture } \\
\text { hay }\end{array}$ & Pasture & $\begin{array}{c}\text { Pasture } \\
\text { silage }\end{array}$ & Wheat & Oats \\
\hline Dry mater $(\%)$ & 12.8 & 19.4 & 82.5 & 19.8 & 40.8 & 85.1 & 84.7 \\
\hline Crude protein (\%) & 26.5 & 9.4 & 7.4 & 18.8 & 13.6 & 13.7 & 13.1 \\
\hline Metabolizable energy $\left(\mathrm{Mcal} \mathrm{kg}^{-1}\right)$ & 2.75 & 2.54 & 2.04 & 2.84 & 2.50 & 3.20 & 2.70 \\
\hline Ash (\%) & 10.9 & 8.2 & 7.3 & 9.8 & 11.6 & 1.5 & 2.6 \\
\hline Ether extract $(\%)$ & 2.8 & 3.4 & 1.3 & 4.0 & 2.6 & 1.3 & 2.8 \\
\hline Neutral Detergent Fibre (\%) & 44.5 & 58.3 & 67.0 & 43.1 & 52.2 & 12.0 & 32.0 \\
\hline \multicolumn{8}{|c|}{ Fatty acids (g $100 \mathrm{~g}-1$ of total fatty acids) } \\
\hline $\mathrm{C} 14: 0$ & 0.0 & 1.0 & 0.7 & 0.2 & 0.0 & 0.0 & 0.0 \\
\hline $\mathrm{C} 15: 1$ & 4.3 & 4.3 & 5.3 & 5.0 & 3.5 & 0.0 & 0.0 \\
\hline $\mathrm{C} 16$ & 16.5 & 20.6 & 28.4 & 13.1 & 21.1 & 18.9 & 15.1 \\
\hline C16:1 & 2.1 & 1.5 & 1.5 & 2.3 & 1.5 & 0.0 & 0.0 \\
\hline $\mathrm{C} 18$ & 1.5 & 1.8 & 4.0 & 1.5 & 1.2 & 1.2 & 2.6 \\
\hline C18:1 n-9 & 1.6 & 3.9 & 11.2 & 1.4 & 1.7 & 15.1 & 40.3 \\
\hline C18:2 n-6 & 12.1 & 21.4 & 23.6 & 8.2 & 13.8 & 60.9 & 40.2 \\
\hline $\mathrm{C} 18: 3 n-3$ & 61.9 & 45.3 & 23.7 & 68.4 & 56.9 & 4.0 & 1.2 \\
\hline $\mathrm{C} 20: 0$ & 0.0 & 0.1 & 1.6 & 0.0 & 0.0 & 0.0 & 0.0 \\
\hline C20:1 & 0.0 & 0.0 & 0.0 & 0.1 & 0.0 & 0.0 & 0.7 \\
\hline
\end{tabular}

The cold carcass weights and the $\mathrm{pH}$ values were measured $24 \mathrm{~h}$ postmortem at the abattoir. Three $\mathrm{pH}$ measurements were taken per carcass with a $\mathrm{pH}$ penetration electrode (Hanna FC232) of a portable pH-meter (Hanna 99163; Hanna Instruments, Woonsocket, RI, USA). A section of the longissimus lumborum (LL) was removed from each carcass and was cut into three equal parts that were vacuum packaged and stored frozen at $-18 \pm 2{ }^{\circ} \mathrm{C}$ until analysis. The cranial part was used for the sensory analysis, the middle part for the color and texture analyses and the caudal part for the intramuscular fat and fatty acid analyses.

\section{Sensory analysis}

An eleven-member trained panel participated in the sensory analysis. The training and testing sessions were conducted at the sensory laboratory of INIA Remehue (Osorno, Chile). The panelists were selected from a group of 30 people without previous experience in sensory evaluation; the panelists were trained following the standards of ASTM and ISO. The sensory laboratory was designed according to ISO standards with separate booths, and the samples were evaluated in a sequence established to avoid the effect of sample order presentation and the first-order or carry-over effects.

The assessors evaluated the beef color intensity, fat color intensity and level of marbling in five raw steaks per session and the beef flavor, tenderness and juiciness in cooked samples. The panelists evaluated the cooked samples in duplicate and analyzed five samples per session.

Immediately after the visual evaluations, the steaks were covered with aluminum foil and cooked in a preheated oven (EKA®, KF 620; Famava, Santiago, Chile) at $170{ }^{\circ} \mathrm{C}$ until an internal temperature of 
$71{ }^{\circ} \mathrm{C}$ was reached, which was determined with individual thermocouples inserted into the geometric center of each steak. The cooked steaks were diced into pieces of $20 \mathrm{~mm}$ ' $20 \mathrm{~mm}^{\prime} 25 \mathrm{~mm}$ (length $\times$ width $\times$ height), placed in coded trays and served to the assessors. The descriptors were quantified using a hybrid scale that ranged from 0 (absence) to 10 (maximum intensity).

\section{Color and texture}

The steaks were allowed to bloom for $30 \mathrm{~min}$ at room temperature before the analysis. The instrument color measurements were recorded for $L^{*}$ (lightness: $0=$ black to $100=$ white), $a^{*}$ (redness/ greenness: positive values, red; negative values, green), and $b^{*}$ (yellowness/blueness: positive values, yellow; negative values, blue) using a Minolta chromameter (CR-400; Minolta Inc., Osaka, Japan) with illuminat $\mathrm{D}_{65}$ and a $2^{\circ}$ viewing angle. The readings were taken from three randomly selected locations of the upper surface of each steak to obtain a representative reading of the surface color. The instrument color of the external fat surface was also measured.

After measuring the color, two steaks were used to determine shear force. The cooking procedure was the same as for the sensory evaluation. After cooking, the steaks were wrapped with film and stored for $24 \mathrm{~h}$ at $4 \pm 2{ }^{\circ} \mathrm{C}$. Subsequently, at least six cores $13 \mathrm{~mm}$ in diameter were obtained from each steak for the Warner-Bratzler shear force (WBSF) analysis, which followed the USDA methodology. The test was performed using a Warner-Bratzler shear blade with a triangular slot cutting edge to record the maximum shear force.

\section{Intramuscular fat}

The intramuscular fat (IMF) was measured with extraction using the Soxhlet equipment with petroleum ether (AOAC, 2005), after removing all external fat from the steaks.

\section{Fatty acid composition}

Samples of $10 \mathrm{~g}$ and $35 \mathrm{~g}$ were used for the fatty acid analyses of meats and fresh pastures, respectively. The fat was extracted according to Bligh and Dyer (1959), as modified by Lumley and Colwell (1991). Briefly, the samples were thawed and ground and then were extracted using methanol, chloroform and water (80:50:32 mL). Subsequently, the samples were homogenized for $30 \mathrm{~min}$. and then filtrated through filter paper using a glass funnel. Water was added until biphasic separation was observed and the fat was concentrated in the chloroform layer. The chloroform phase was collected and removed by evaporation, and 2.0 $\mathrm{mL}$ of $\mathrm{n}$-hexane was added to the extract, which was then stored at $-18 \pm 2{ }^{\circ} \mathrm{C}$ until the analysis. Approximately $0.5 \mathrm{~g}$ of fat was obtained with this extraction. Before the fatty acid extraction, C23:0 (Nu-Chek Prep Inc. Elysian, MN, USA) was added to the samples as an internal standard. The meat samples were methylated according to Ichihara et al. (1996) and the pasture samples according to Hartman and Lago (1973). The samples were analyzed with a gas chromatograph (GC-2010 Plus; Shimadzu ${ }^{\circledR}$, Kyoto, Japan) equipped with an FID detector. A capillary column SP-2560 ${ }^{\mathrm{TM}}$ (Sigma-Aldrich Co., Bellefonte, PA, USA) of $100 \mathrm{~m} \times 0.25 \mathrm{~mm} \times 0.25 \mu \mathrm{m}$ film was used, with helium as the carrier gas at $1.0 \mathrm{~mL} \mathrm{~min}^{-1}$ and an inlet pressure of $15 \mathrm{psi}$, and the method of injection was split (100:1). The injector temperature was fixed at $250{ }^{\circ} \mathrm{C}$ and the detector temperature at $260{ }^{\circ} \mathrm{C}$. The injected sample volume was 1.0 $\mu \mathrm{L}$, and the oven temperature was programmed to increase from $140{ }^{\circ} \mathrm{C}$ (maintained for $5 \mathrm{~min}$ ) to $240{ }^{\circ} \mathrm{C}$ (maintained for $15 \mathrm{~min}$ ) at $4{ }^{\circ} \mathrm{C} \mathrm{min}^{-1}$. The fatty acids were identified by comparison of the retention times of the chromatograph peaks with those of the methyl esters from a mixture prepared with a FAME standard of 37 components (Standard: 47885-U; Sigma-Aldrich Co., St. Louis, MO, USA), a C18:1 $t$-11 methyl ester standard (Standard: 46905-U; Sigma-Aldrich Co., St. Louis, MO, USA), a conjugated linoleic acid (CLA) $c$-9 $t$-11 methyl acid (Standard: 10-1823-7; 
Larodan AB, Malmo, Sweden), and a PUFA-2 (Supelco Analytical, USA). The C23:0 was used as an internal standard (NU-CheckPrep, Inc., Elysian, USA).

\section{Statistical analyses}

The physicochemical and sensory data were analyzed with ANOVA using the General Linear Model (GLM) procedure of the SAS statistical software package (SAS Institute Inc., Cary, NC, USA), with the type of finishing diet (SO, LO, SW, LW and $\mathrm{P}$ ) as a fixed effect in the model. For the sensory data, the session effect was also included in the model as a fixed effect. Least-square means were separated with Tukey's studentized range tests.

The CORR procedure of SAS was used to calculate the linear correlations between marbling and IMF.

\section{Results and discussion}

\section{Physicochemical and sensory evaluations}

The physicochemical and sensory attributes of beef from the different dietary treatments are shown in Table 2. There were no differences $(\mathrm{P}>0.05)$ in $\mathrm{pH}$ values among the treatments, with an average $\mathrm{pH}$ of 5.64, which was within the normal range for beef. Significant differences in instrument meat redness $\left(a^{*}\right)$ were detected among the treatments. The beef from SW, SO and LW was redder than beef from pasture-finished cattle. Similarly, the beef from the SW treatment was higher than beef from the P-treatment for red color intensity, as evaluated by a trained panel. The instrument color lightness $\left(L^{*}\right)$ and yellowness $\left(b^{*}\right)$ also differed significantly $(\mathrm{P} \leq 0.05)$ among the treatments. The SW beef was higher than $\mathrm{P}$ beef for $L^{*}$, and the $\mathrm{P}$ beef was lower for $b^{*}$ than the other treatments, with the exception of the LO beef. The beef from the P-treatment was darker than the beef from grain-finished animals. Other authors also found that the muscles from pasture-fed animals were darker than the muscles from grain-fed cattle (Realini et al., 2004).

The $L^{*}$ values for external fat color were higher for the beef from all grain treatments than for the beef of the P-treatment. Similarly, the external fat color of beef that was assessed by panelists from pasture-fed animals was more intense $(\mathrm{P} \leq 0.05)$ than that from the other treatments, with the exception of the SW beef. Pasture-fed beef often contains yellow fat because of the high carotenoid content of pastures, whereas the fat from feedlot beef tends to be white (Yang et al., 2002).

The beef from the LW treatment had a higher percentage of intramuscular fat (IMF) than the beef from the LO, SW and P treatments. However, marbling scores assigned by the trained panelists were higher for P than for LO beef, with no significant differences among the other treatments. A correlation of 0.46 was observed between the marbling assessed by the trained panelists and the percentage of IMF. Correlations between marbling and IMF are highly variable, and previous studies reported a range from 0.32 to 0.79 (Kruk et al., 2002). This wide range could be caused by many factors, such as the range of IMF content, the range of marbling scores, the method to extract intramuscular fat, and the visual contrast of the fat color with the background color of the meat, among others (Kruk et al., 2002). The visual assessment of fat against a darker lean background might have overestimated the marbling score in beef from the P-treatment, compared with beef from the other diets.

The Warner-Bratzler shear force was higher in beef from the SO, LO and SW treatments than beef from the pasture treatment. These results are consistent with those reported by Realini et al. (2004) and Del Campo et al. (2008), who also found that beef from pasture-fed animals had lower shear force values than beef from grain-finished cattle. Similarly, the trained panelists assigned higher tenderness scores to the beef from the pasture treatment than to the beef from LW and LO diets. 
Table 2. Physicochemical and sensory attributes of beef affected by dietary treatment $(\mathrm{n}=15$ per treatment).

\begin{tabular}{|c|c|c|c|c|c|c|}
\hline & $\mathrm{SO}$ & LO & SW & LW & $\mathrm{P}$ & RMSE \\
\hline \multicolumn{7}{|c|}{ Physicochemical variables } \\
\hline $\mathrm{pH}$ & 5.63 & 5.63 & 5.63 & 5.64 & 5.64 & 0.057 \\
\hline Shear force (kgf) & $3.47 \mathrm{a}^{1}$ & $3.33 \mathrm{a}$ & $3.35 \mathrm{a}$ & $3.16 \mathrm{ab}$ & $2.85 \mathrm{~b}$ & 0.655 \\
\hline \multicolumn{7}{|l|}{ Lean color } \\
\hline$L^{*}$ & $33.69 \mathrm{ab}$ & $33.73 \mathrm{ab}$ & $34.43 \mathrm{a}$ & $34.23 \mathrm{ab}$ & $32.55 \mathrm{~b}$ & 2.556 \\
\hline$a^{*}$ & $21.35 \mathrm{a}$ & $20.49 \mathrm{ab}$ & $22.16 \mathrm{a}$ & $21.14 \mathrm{a}$ & $18.84 \mathrm{~b}$ & 2.812 \\
\hline$b^{*}$ & $11.23 \mathrm{ab}$ & $10.24 \mathrm{bc}$ & $11.76 \mathrm{a}$ & $10.78 \mathrm{ab}$ & $9.20 \mathrm{c}$ & 1.804 \\
\hline \multicolumn{7}{|l|}{ Fat color } \\
\hline$L^{*}$ & $69.35 \mathrm{a}$ & $65.18 \mathrm{bc}$ & 68.77 a & $66.16 \mathrm{ab}$ & $62.18 \mathrm{c}$ & 4.382 \\
\hline$a^{*}$ & 5.86 & 5.47 & 6.49 & 6.80 & 6.13 & 2.155 \\
\hline$b^{*}$ & $14.29 \mathrm{a}$ & $11.87 \mathrm{~b}$ & $14.21 \mathrm{a}$ & $13.60 \mathrm{ab}$ & $14.64 \mathrm{a}$ & 2.694 \\
\hline Intramuscular fat (\%) & $3.17 \mathrm{ab}$ & $2.67 \mathrm{~b}$ & $2.81 \mathrm{~b}$ & $3.90 \mathrm{a}$ & $2.42 \mathrm{~b}$ & 1.113 \\
\hline \multicolumn{7}{|c|}{ Sensory attributes (Scale from 0 to 10 ) } \\
\hline Marbling & $3.7 \mathrm{ab}^{1}$ & $3.3 \mathrm{~b}$ & $3.5 \mathrm{ab}$ & $3.8 \mathrm{ab}$ & $3.9 \mathrm{a}$ & 1.204 \\
\hline Red color intensity & $4.8 \mathrm{ab}$ & $4.9 \mathrm{ab}$ & $5.0 \mathrm{a}$ & $4.7 \mathrm{ab}$ & $4.6 \mathrm{~b}$ & 1.240 \\
\hline External fat color & $3.2 \mathrm{~b}$ & $3.0 \mathrm{~b}$ & $3.5 \mathrm{ab}$ & $3.1 \mathrm{~b}$ & $3.6 \mathrm{a}$ & 1.207 \\
\hline Juiciness & $4.2 \mathrm{a}$ & $3.5 \mathrm{~b}$ & $4.0 \mathrm{ab}$ & $3.8 \mathrm{ab}$ & $3.8 \mathrm{ab}$ & 1.763 \\
\hline Tenderness & $4.8 \mathrm{ab}$ & $4.3 \mathrm{bc}$ & $4.4 \mathrm{ab}$ & $3.9 \mathrm{c}$ & $5.0 \mathrm{a}$ & 1.888 \\
\hline Flavor & $4.8 \mathrm{~b}$ & $5.2 \mathrm{ab}$ & $4.9 \mathrm{ab}$ & $5.0 \mathrm{ab}$ & $5.3 \mathrm{a}$ & 1.285 \\
\hline
\end{tabular}

${ }^{1}$ The same letters in a row indicate there are no significant differences $(\mathrm{P}>0.05)$.

RMSE: Root-mean-square error.

$\mathrm{SO}=$ Steers finished with oat grain $(1.0 \%$ of live weight $)$ and pasture silage $(2.0 \%$ of live weight $)$ for $35 \mathrm{~d}$.

$\mathrm{LO}=$ Steers finished with oat grain $(1.0 \%$ of live weight $)$ and pasture silage $(2.0 \%$ of live weight $)$ for $75 \mathrm{~d}$.

$\mathrm{SW}=$ Steers finished with wheat grain $(1.0 \%$ of live weight $)$ and pasture silage $(2.0 \%$ of live weight $)$ for $35 \mathrm{~d}$.

$\mathrm{LW}=$ Steers finished with wheat grain (1.0\% of live weight) and pasture silage ( $2.0 \%$ of live weight) for $75 \mathrm{~d}$.

$\mathrm{P}=$ Steers finished on pasture for $90 \mathrm{~d}$.

$\mathrm{L}^{*}$ : lightness: $0=$ black, $100=$ white.

$\mathrm{a}^{*}$ : redness/greenness: positive values, red; negative values, green.

$\mathrm{b}^{*}$ : yellowness/blueness: positive values, yellow; negative values, blue.

The beef flavor scores were higher $(\mathrm{P} \leq 0.05)$ for the $\mathrm{P}$ than the SO treatment, with no differences ( $\mathrm{P}>0.05$ ) among the other treatments. Additionally, the trained panel found that the beef from the SO treatment was higher than the LO beef for juiciness.

\section{Intramuscular fatty acid composition}

The intramuscular fatty acid composition is shown in Table 3 for the beef of all dietary treatments. The intramuscular fat from steers fed the P-diet had lower $(\mathrm{P} \leq 0.05)$ levels of $\mathrm{C} 14: 0$ and $\mathrm{C} 16: 0$ than the fat from the LW treatment, whereas the beef from the LW diet was lower than the LO, SW and P beef in C18:0 content. No differences were observed among the treatments for C15:0, C17:0, C20:0 and C22:0 fatty acids. The intramuscular fat of beef from the LO and SW treatments had higher values of all saturated fatty acids (SFA) than the pasture-fed beef $(\mathrm{P} \leq 0.05)$. 
Table 3. Intramuscular fatty acid composition (g $100 \mathrm{~g}^{-1}$ of total fatty acids) of beef affected by dietary treatment $(n=15$ per treatment).

\begin{tabular}{|c|c|c|c|c|c|c|}
\hline Fatty acid & $\mathrm{SO}$ & LO & SW & LW & $\mathrm{P}$ & RMSE \\
\hline C14:0 & $2.14 \mathrm{ab}^{1}$ & $2.17 \mathrm{ab}$ & $2.17 \mathrm{ab}$ & $2.34 \mathrm{a}$ & $1.94 \mathrm{~b}$ & 0.403 \\
\hline C15:0 & 0.31 & 0.32 & 0.35 & 0.32 & 0.33 & 0.087 \\
\hline C16:0 & $26.0 \mathrm{ab}$ & $25.6 \mathrm{bc}$ & $26.0 \mathrm{ab}$ & $26.9 \mathrm{a}$ & $24.5 \mathrm{c}$ & 1.499 \\
\hline $\mathrm{C} 17: 0$ & 0.83 & 0.79 & 0.88 & 0.82 & 0.81 & 0.128 \\
\hline C18:0 & $14.2 \mathrm{ab}$ & $14.9 \mathrm{a}$ & $14.7 \mathrm{a}$ & $12.9 \mathrm{~b}$ & $14.5 \mathrm{a}$ & 1.826 \\
\hline C20:0 & 0.10 & 0.09 & 0.09 & 0.08 & 0.06 & 0.048 \\
\hline $\mathrm{C} 22: 0$ & 0.07 & 0.10 & 0.06 & 0.06 & 0.10 & 0.062 \\
\hline SFA & $43.7 \mathrm{ab}$ & $44.0 \mathrm{a}$ & $44.3 \mathrm{a}$ & $43.5 \mathrm{ab}$ & $42.2 \mathrm{~b}$ & 2.114 \\
\hline C14:1 & $0.61 \mathrm{ab}$ & $0.59 \mathrm{ab}$ & $0.58 \mathrm{ab}$ & $0.73 \mathrm{a}$ & $0.52 \mathrm{~b}$ & 0.238 \\
\hline $\mathrm{C} 16: 1$ & $4.05 \mathrm{ab}$ & $3.92 \mathrm{ab}$ & $3.82 \mathrm{ab}$ & $4.50 \mathrm{a}$ & $3.81 \mathrm{~b}$ & 0.876 \\
\hline $\mathrm{C} 17: 1$ & $0.65 \mathrm{~b}$ & $0.63 \mathrm{~b}$ & $0.69 \mathrm{ab}$ & $0.80 \mathrm{a}$ & $0.69 \mathrm{ab}$ & 0.150 \\
\hline $\mathrm{C} 18: 1 t-11$ & $1.05 \mathrm{~b}$ & $1.10 \mathrm{~b}$ & $1.27 \mathrm{~b}$ & $1.05 \mathrm{~b}$ & $1.62 \mathrm{a}$ & 0.480 \\
\hline C18:1 $c-9$ & 41.5 & 40.5 & 39.9 & 41.8 & 41.8 & 2.692 \\
\hline C18:1 c-7 & 1.29 & 1.15 & 1.31 & 1.41 & 1.21 & 0.361 \\
\hline $\mathrm{C} 20: 1$ & 0.14 & 0.11 & 0.12 & 0.13 & 0.12 & 0.126 \\
\hline MUFA & 49.4 & 48.0 & 47.8 & 50.4 & 48.4 & 2.877 \\
\hline $\mathrm{C} 18: 2 n-6$ & 3.09 & 3.62 & 3.36 & 2.84 & 3.02 & 1.246 \\
\hline C18:2 n-6 trans & $0.14 \mathrm{~b}$ & $0.14 \mathrm{~b}$ & $0.15 \mathrm{~b}$ & $0.16 \mathrm{~b}$ & $0.26 \mathrm{a}$ & 0.077 \\
\hline CLA C18:2 $c-9 t-11$ & $0.37 \mathrm{bc}$ & $0.36 \mathrm{bc}$ & $0.44 \mathrm{~b}$ & $0.34 \mathrm{c}$ & $0.55 \mathrm{a}$ & 0.123 \\
\hline $\mathrm{C} 18: 3 n-6$ & $0.06 \mathrm{a}$ & $0.06 \mathrm{a}$ & $0.04 \mathrm{ab}$ & $0.04 \mathrm{ab}$ & $0.01 \mathrm{~b}$ & 0.044 \\
\hline $\mathrm{C} 18: 3 n-3$ & $0.90 \mathrm{bc}$ & $0.78 \mathrm{bc}$ & $1.03 \mathrm{~b}$ & $0.64 \mathrm{c}$ & $1.52 \mathrm{a}$ & 0.424 \\
\hline $\mathrm{C} 20: 2 c-11 c-14$ & 0.01 & 0.02 & 0.01 & 0.01 & 0.01 & 0.013 \\
\hline $\mathrm{C} 20: 3 n-6$ & $0.36 \mathrm{ab}$ & $0.39 \mathrm{a}$ & $0.41 \mathrm{a}$ & $0.32 \mathrm{ab}$ & $0.22 \mathrm{~b}$ & 0.194 \\
\hline C20:4 n-6 & 1.41 & 1.70 & 1.44 & 1.24 & 1.50 & 0.719 \\
\hline C20:5 n-3, EPA & $0.10 b c$ & $0.04 b c$ & $0.14 b$ & $0.03 \mathrm{~d}$ & $0.29 \mathrm{a}$ & 0.084 \\
\hline C22:5 n-3, DPA & $0.64 \mathrm{bc}$ & $0.65 \mathrm{bc}$ & $0.75 \mathrm{~b}$ & $0.44 \mathrm{c}$ & $1.03 \mathrm{a}$ & 0.385 \\
\hline $\mathrm{C} 22: 6 n-3, \mathrm{DHA}$ & 0.16 & 0.14 & 0.16 & 0.12 & 0.14 & 0.097 \\
\hline PUFA & $7.30 \mathrm{ab}$ & $8.01 \mathrm{ab}$ & $8.01 \mathrm{ab}$ & $6.23 \mathrm{~b}$ & $8.64 \mathrm{a}$ & 2.948 \\
\hline $\mathrm{P}: \mathrm{S}$ & $0.17 \mathrm{ab}$ & $0.18 \mathrm{ab}$ & $0.18 \mathrm{ab}$ & $0.15 b$ & $0.21 \mathrm{a}$ & 0.073 \\
\hline$n-6$ & 5.43 & 6.28 & 5.85 & 4.94 & 5.56 & 2.116 \\
\hline$n-3$ & $1.79 \mathrm{bc}$ & $1.61 \mathrm{bc}$ & $2.09 \mathrm{~b}$ & $1.22 \mathrm{c}$ & $2.98 \mathrm{a}$ & 0.909 \\
\hline$n-6: n-3$ & $3.10 \mathrm{~b}$ & $4.01 \mathrm{a}$ & $2.87 \mathrm{~b}$ & $4.09 \mathrm{a}$ & $2.11 \mathrm{c}$ & 0.720 \\
\hline
\end{tabular}

${ }^{1}$ The same letters in a row indicate there are no significant differences $(\mathrm{P}>0.05)$.

RMSE: root-mean-square error; CLA: conjugated linoleic acid; EPA: eicosapentaenoic acid; DPA: docosapentaenoic acid; SFA: saturated fatty acids, C14:0 + C16:0 + C17:0 + C18:0 + C20:0 + C24:0; MUFA: monounsaturated fatty acids, C14:1+ C16:1 + C17:1 + C18:1 c-9 + C18:1 c-7 + C18:1 t-11 + C20:1; PUFA: polyunsaturated fatty acids, C18:2 n-6 + C18:2 n-6 trans + C18:3 n-3 + C18:3 n-6 + C20:3 n-6 + C20:3 n-3 + C20:5 n-3; C22:6 n-3 + CLA c-9 t-11. P:S: polyunsaturated:saturated fatty acid ratio; n-6:n-3, fatty acid ratio. $\mathrm{SO}=$ Steers finished with oat grain $(1.0 \%$ of live weight $)$ and pasture silage $(2.0 \%$ live weight $)$ per $35 \mathrm{~d}$.

$\mathrm{LO}=$ Steers finished with oat grain ( $1.0 \%$ live weight) and pasture silage $(2.0 \%$ of live weight) for $75 \mathrm{~d}$.

$\mathrm{SW}=$ Steers finished with wheat grain $(1.0 \%$ of live weight $)$ and pasture silage $(2.0 \%$ of live weight $)$ for $35 \mathrm{~d}$.

$\mathrm{LW}=$ Steers finished with wheat grain (1.0\% of live weight) and pasture silage ( $2.0 \%$ of live weight) for $75 \mathrm{~d}$. $\mathrm{P}=$ Steers finished on pasture for $90 \mathrm{~d}$. 
The intramuscular fat of the longissimus lumborum muscle from the LW treatment had higher percentages of C14:1 and C16:1 than the corresponding fat from the pasture treatment and a higher percentage of C17:1 than the fat from the oat treatments $(\mathrm{P} \leq 0.05)$. There were no differences among the treatments in the percentages of total monounsaturated fatty acids (MUFA), oleic acid (C18:1 c-9), C18:1 c-7 and C20:1 ( $\mathrm{P}>0.05)$.

The intramuscular fat from animals fed on pasture had a higher percentage of C18:1 $t-11$ (vaccenic acid) than that from the other finishing treatments $(\mathrm{P} \leq 0.05)$, which was consistent with other studies (Leheska et al., 2008; García et al., 2008). The C18:1 $t$-11 is an intermediate in the biohydrogenation of linoleic (C18:2 n-6) and linolenic (C18:3 $n-3)$ acids and was higher in beef from pasture-fed cattle. This particular fatty acid is of great interest because it is converted to conjugated linoleic acid (CLA) $c-9 t$-11 through endogenous desaturation in the host animal tissue (Kalač and Samková, 2010; Dilzer and Park, 2012).

The beef from the P-treatment had a higher percentage of all PUFAs than the LW beef $(\mathrm{P} \leq 0.05)$. Additionally, the beef from the P-treatment had higher percentages of C18:2 $t-6, \mathrm{C} 18: 3 n-3$, CLA $c-9 t-11, \mathrm{C} 20: 5 n-3 \mathrm{EPA}$, and C22:5 n-3 DPA fatty acids $(\mathrm{P} \leq 0.05)$ than the other dietary treatments. By contrast, the beef from the oat treatments was higher in C18:3 n-6 fatty acid content than that from the P-treatment $(\mathrm{P} \leq 0.05)$, whereas the beef from the LO and SW treatments had higher contents of C20:3 n- 6 than the beef from the Ptreatment $(\mathrm{P} \leq 0.05)$. The percentages of all PUFAs were similar to those reported in other studies that used different sources of feed (Garcia et al., 2008; Morales et al., 2012).

The content of conjugated linoleic acid $c-9 t-11$ was higher $(\mathrm{P} \leq 0.05)$ in beef from steers finished on pasture than in beef from the other treatments. Conjugated linoleic acid $c-9 t-11$ is produced as an intermediate of the biohydrogenation process that occurs in the rumen in which dietary unsaturated fatty acids (primarily C18:2 n-6 and C18:3n-3) undergo successive steps of isomerization and reduction (Kalač and Samková, 2010). The concentration of conjugated linoleic acid $c-9 t-11$ in adipose tissue is higher when animals are fed on pasture than when fed on stored forage or grain (Schor et al., 2008). Other studies also showed that steers finished on pasture had higher beef contents of CLA $c-9 t-11$ than those finished on grain-based diets (Realini et al., 2004; Garcia et al., 2008; Leheska et al., 2008; De la Fuente et al., 2009).

The time of feeding with wheat had a significant effect on the fatty acid profile of beef. The percentages of C18:0, CLA $c-9 t-11, \mathrm{C} 18: 3 n-3, \mathrm{C} 20: 5 n-3$, and $\mathrm{C} 22: 5 n-3$ were higher for beef from the SW than from the LW treatment $(\mathrm{P} \leq 0.05)$, whereas there were no differences between the oat treatments. Aldai et al. (2011) reported that beef from steers finished for two months on grains (primarily barley) had similar levels of CLA $c-9 t-11$, C20:5 $n-3$, and C22:5 n-3 but a lower level of C18:3 n-3 than beef finished for one month on grains. Aldai et al. (2012) highlighted that the concentrations of fiber and starch in the rumen affected the fatty acid metabolism. In this respect, wheat had a lower proportion of NDF (Table 1), and it is well documented that wheat has higher starch content than oats (Shewry, 2009). However, the $\mathrm{pH}$ of the rumen is primarily influenced by the fermentable carbohydrate in the diet, and the amount and source of starch and/or the rate of ruminal degradation of starch affects biohydrogenation in the rumen (Mohammed et al., 2010). Wheat grain reduces the ruminal $\mathrm{pH}$ and is used to induce subacute ruminal acidosis (SARA); subacute ruminal acidosis results in changes of the fermentation pattern in the rumen, with possible changes in the production of fatty acids (Enjalbert et al., 2008). These authors reported that diets with 20 and $34 \%$ wheat induced a marginal or a severe SARA, respectively. In the present study, although approximately $30 \%$ of the diet was wheat grain, the steers fed wheat did not show symptoms of SARA. However, the proportion used could have 
affected the ruminal $\mathrm{pH}$, which then affected the IMF fatty acid profile. Enjalbert et al. (2008) reported lower contents of C18:0 and CLA $c-9$ $t$-11 in milk fat when wheat grain was added to the diet to induce SARA. Colman et al. (2010) also found that the concentrations of C18:0 and CLA $c-9 t-11$ in milk fat were lower in the third week postinduction of mild SARA with wheat grain in the diet.

For the diets with oats, the quantity of oil in the oats could have influenced the results. In the present study, the ether extract was twofold greater in oats than that in wheat (Table 1). Previous studies investigated the effect of naked oats in feed on the fatty acid composition of milk (Woods and Fearon, 2009), and the milk fat from early and midlactation cows fed a naked oat diet (plus ad libitum grass silage) had higher levels of unsaturated fats (primarily C18:1) and lower levels of saturated fatty acids (C12:0, C14:0 and C16:0) than milk fat from animals fed a barley diet (Fearon et al., 1996). However, diets with oats favor the primary rumen PUFA-biohydrogenation pathway (associated with modification of ruminal bacterial populations), which induces more complete hydrogenation of unsaturated fatty acids in the diet (Gómez-Cortés et al., 2009). Moreover, microorganisms in the rumen adapt to an increase in the unsaturated oil content of the diet, so the biohydrogenation capacity increases with a higher number and/or activity of competent bacteria (Zened et al., 2012). Further studies are needed to evaluate the effects of including naked oats in the diet on the content and composition of intramuscular fat in steers.

The attention focused on the ratio between $n-6$ and $n-3$ fatty acids is considerable. A high $n-6: n-3$ ratio is considered a risk factor for certain cancers and coronary heart diseases (Hibbeln et al., 2006), and an $n-6: n-3$ ratio for beef of 4.0 or less is recommended. The $\mathrm{P}, \mathrm{SO}$ and $\mathrm{SW}$ treatments (35 d) had beef with $n-6: n-3$ ratios lower than 4.0 , with the lowest ratio in beef from the pasture treatment, which was consistent with other studies (Schor et al., 2008; De la Fuente et al., 2009;
Morales et al., 2012). These results highlighted the importance of the concentrate:forage ratio of the diet; to produce beef with a favorable $n-6: n-3$ ratio, feeding grass silage plus grain for $35 \mathrm{~d}$, but not for $75 \mathrm{~d}$, is a suitable alternative to pasture. Fredriksson, Eriksson and Pickova (2007) also found an increase in the $n-6: n-3$ ratio and a decrease in the total PUFA content of muscle tissue of steers fed silage plus grain (wheat and oats) for the final four months compared with steers that finished on pasture. Similarly, Klee et al. (2011) found higher $n-6: n-3$ ratios in tenderloin and round cuts from steers fed on pasture plus oat grain than in those cuts from steers fed only on pasture. Aldai et al. (2011) reported lower $n-6: n-3$ ratios in beef from steers finished on pasture than from those fed on intensive grains (primarily barley). Additionally, the highest $n-6: n-3$ ratio was found in beef from steers fed grain for two months compared with one month. Other studies also showed that diets high in concentrates negatively affected the $n$ 6:n-3 fatty acid ratio (Realini et al., 2004; De la Fuente et al., 2009).

In the present study, animals were maintained in similar preexperimental conditions (Table 1). Although the time on feed in the preexperimental phase could have affected the results of the experiment, previous studies indicated that feeding during the background phase marginally affected the quality of beef. Moreover, Duckett et al. (2009) found no effect of the level of supplementation during the winter background on beef quality of pasture- or concentrate-finished steers. Similarly, Chicatún et al. (2006) evaluated the beef quality of steers not supplemented or supplemented with two levels of corn silage during the growing phase and three levels of corn grain during the finishing phase, and the authors found no significant effect of the background feeding on the quality of beef. Finally, Pordomingo et al. (2012) evaluated four background strategies, i.e., 100\% pasture and three different levels of alfalfa hay (40, 70 and 100\%) with concentrate, before finishing on pasture. The authors found residual effects of the background strategies on the intramuscular fat of pasture- 
finished animals; the pasture and 100\% alfalfa hay treatments had beef with higher concentrations of CLA $c-9 t-11$ and 18:3 n-3 and a lower $n-6: n-3$ ratio, although the differences among the treatments were marginal.

The beef from pasture-fed steers tended to be tenderer, darker, less red and with yellower fat than the beef from grain-fed steers. The beef from steers fed silage plus wheat for $75 \mathrm{~d}$ had lower tenderness scores than the beef from short-term feeding on grain. The beef from pasture-fed steers had a more favorable fatty acid profile, with higher levels of CLA $c-9 t-11$ and $n-3$ fatty acids and a lower $n-6: n-3$ fatty acid ratio than the beef from grain-fed steers. The time feeding on silage plus grain had a significant effect on the fatty acid composition of beef when feeding the steers wheat but not oats. Moreover, the $n-6: n-3$ ratio of beef was more favorable when steers were fed silage plus wheat or oats for a shorter time compared with a longer finishing time ( 35 vs. $75 \mathrm{~d}$ ).

\section{Acknowledgements}

This work was funded by FONDECYT project 11090062. We thank CONICYT (PDA08) for supporting Rodrigo Morales's postdoctoral studies with a scholarship under the Programa Bicentenario de Ciencia y Tecnología (PBCT) (Chile). We are also grateful to Rene Gonzalez and Robinson Cárdenas for sample analyses and to the slaughterhouse staff, Rodrigo Vergara and Astrid Hernandez at FRIGOSORNO S.A. (Chile), for their cooperation.

\section{Resumen}

R. Morales, J. Parga, I. Subiabre y C.E. Realini. 2015. Estrategias para novillos en engorda a base de pradera o ensilaje más grano y el tiempo de alimentación y sus efectos sobre la calidad de la carne. Cien. Inv. Agr. 42(1): 5-18. El objetivo del presente estudio fue comparar la calidad de carne de novillos finalizados con pradera y grano, como también, evaluar el impacto de dos periodos de finalización con grano. Un grupo de 75 novillos se alimentó en cinco diferentes dietas: ( $n=15$ por dieta): pradera por 90 días $(\mathrm{P})$, avena más ensilaje de pradera por 35 días (SO), avena más ensilaje de pradera por 75 días (LO), trigo más ensilaje de pradera por 35 días (SW) y trigo más ensilaje de pradera por 75 días. En el músculo longissimus lumborum, se determinaron análisis fisicoquímicos, sensoriales y de ácidos grasos. La carne de los animales alimentados en pradera tiende a ser más tierna, oscura, menos roja y con una grasa más amarilla que la obtenida a partir de granos. La carne de novillos alimentados con trigo más ensilaje por 75 días tiene menor terneza que la obtenida en la engorda con grano más ensilaje por 35 días. La carne de novillos finalizados a pradera tiene mayores niveles de ácido linoleico conjugado $c-9 t-11$, ácidos grasos $n-3$ y un baja relación de los ácidos grasos n-6:n-3 en comparación de la carne obtenida de novillos alimentados con granos más ensilaje. El tiempo en grano más ensilaje tiene un efecto significativo en la composición de ácidos grasos de la carne cuando se utiliza el grano de trigo pero no la avena. Sin embargo, la relación de los ácidos grasos n-6:n-3 de la carne fue más favorable cuando los novillos fueron alimentados con grano (trigo o avena) más ensilaje por 35 días en comparación a los engordados por 75 días.

Palabras clave: Ácidos grasos, ALC, calidad de carnes, novillos Holstein Friesian. 


\section{References}

Aldai, N., A.V. Klieve, M.E.R. Dugan, J.K.G. Kramer, D. Ouwerkerk, J.L. Aalhus, J.J. McKinnon, and T.A. McAllister. 2012. Evaluation of rumen fatty acid hydrogenation intermediates and differences in bacterial communities after feeding wheat- or corn-based dried distillers grains to feedlot cattle. Journal Animal Science 90:2699-2709.

Aldai, N., M.E.R. Dugan, J.K.G. Kramer, A. Martínez, O. López-Campos, A.R. Mantecón, and K. Osoro. 2011. Length of concentrate finishing affects the fatty acid composition of grass-fed and genetically lean beef: an emphasis on trans-18:1 and conjugated linoleic acid profiles. Animal 5:1643-1652.

AOAC-Association of Official Analytical Chemists. 2005. Official methods of analysis. $18^{\text {th }} \mathrm{ed}$. AOAC, Washington (DC), USA.

Bligh, E.G., and W.J. Dyer. 1959. A rapid method of total lipid extraction and purification. Canadian Journal of Biochemistry and Physiology 37:911917.

Chicatún, A., F.J. Santini, G.J. Depetris, C. Faverín, and E. Villarreal. 2006. Calidad de la carne de novillos producidos bajo distintas estrategias de suplementación. Revista Argentina Producción Animal 26(sup. 1):409-410.

Colman, E., W.B. Fokkink, M. Craninx, J.R. Newbold, B. De Baets, and V. Fievez. 2010. Effect of induction of subacute ruminal acidosis on milk fat profile and rumen parameters. Journal of Dairy Science 93:4759-4773.

De la Fuente, J., M.T. Díaz, I. Alvarez, M. A. Oliver, M. Font I Furnols, C. Sañudo, M.M. Campo, F. Montossi, G.R. Nute, and V. Cañeque. 2009. Fatty acid and vitamin E composition of intramuscular fat in cattle reared in different production systems. Meat Science 82:331-337.

Del Campo, M., G. Brito, J.M.S. de Lima, D.V. Martins, C. Sañudo, R.S. Julián, P. Hernández, and F. Montossi. 2008. Effects of feeding strategies including different proportion of pasture and concentrate, on carcass and meat quality traits in Uruguayan steers. Meat Science 80:753-760.

Dilzer, A., and Y. Park. 2012. Implication of con- jugated linoleic acid (CLA) in human health. Critical Reviews in Food Science and Nutrition 52:488-513.

Duckett, S.K., J.P.S. Neel, J.P. Fontenot, and W.M. Clapham. 2009. Effects of winter stocker growth rate and finishing system on: III. Tissue proximate, fatty acid, vitamin, and cholesterol content. Journal Animal Science Journal Animal Science 87:2961-2970.

Elgersma, A., S. Tamminga, and G. Ellen. 2006. Modifying milk composition through forage. Animal Feed Science Technology 131:207-225.

Enjalbert, F., Y. Videau, M.C. Nicot, and A. Troegeler-Meynadier. 2008. Effects of induced subacute ruminal acidosis on milk fat content and milk fatty acid profile. Journal of Animal Physiology and Animal Nutrition 92:284-291.

Fearon, A.M., C.S. Mayne, and S. Marsden. 1996. The effect of inclusion of naked oats in the concentrate offered to dairy cows on milk production, milk fat composition and properties. Journal Science Food Agriculture 72:273-282.

Fredriksson Eriksson, S., and J. Pickova. 2007. Fatty acids and tocopherol levels in $M$. longissimus dorsi of beef cattle in Sweden - A comparison between seasonal diets. Meat Science 76:746-754.

Garcia, P.T., N.A. Pensel, A.M. Sancho, N.J. Latimori, A.M. Kloster, M.A. Amigone, and J.J. Casal. 2008. Beef lipids in relation to animal breed and nutrition in Argentina. Meat Science 79:500-508.

Gómez-Cortés, P., P. Frutos, a R. Mantecón, M. Juárez, M. A. De la Fuente, and G. Hervás. 2009. Effect of supplementation of grazing dairy ewes with a cereal concentrate on animal performance and milk fatty acid profile. Journal of Dairy Science 92: 3964-3972.

Hartman, L., Lago, R. 1973. Further observations concerning effects of unsaponifiable constituents on the properties of coffee seed oil. Journal of the American Oil Chemists Society 50:99-100.

Hibbeln J.R., L.R. Nieminen, T.L. Blasbalg, J.A. Riggs, W.E. Lands. 2006. Healthy intakes of n-3 and n-6 fatty acids: estimations considering worldwide diversity. American Journal Clinical Nutrition 83:1483S-1493S.

Ichihara, K., A. Shibahara, K. Yamamoto, and T. Na- 
kayama. 1996. An improved method for rapid analysis of the fatty acids of glycerolipids. Lipids 31:535-539.

Kalač, P., and E. Samková. 2010. The effects of feeding various forages on fatty acid composition of bovine milk fat: A review. Czech Journal Animal Science 55:521-537.

Klee, G., N. Mendoza, and J. Chavarría. 2011. Production and meat fatty acids profile of Hereford steers fed on pasture with and without oat grain supplement. Chile, VIII Region. Ciencia e Investigación Agraria 38:331-338.

Kruk, Z.A. W.S. Pitchford, B.D. Siebert, M.P.B. Deland, and C.D.K. Bottema. 2002. Factors affecting estimation of marbling in cattle and the relationship between marbling scores and intramuscular fat. Proceeding of the Australian Society of Animal Production 24:129-132.

Leheska, J.M., L.D. Thompson, J.C. Howe, E. Hentges, J. Boyce, J.C. Brooks, B. Shriver, L. Hoover, and M.F. Miller. 2008. Effects of conventional and grass-feeding systems on the nutrient composition of beef. Journal of Animal Science 86:3575-3585.

Lumley, I.D., and R.K. Colwell. 1991. Extraction of fats from fatty foods and determination of fat content. p. 227-245. In: Rossell, J.B., and J.L.R. Pritchard (eds.). Analysis of oilseeds, fats and fatty foods. Elsevier Applied Science, London, UK.

Mohammed, R., J.J. Kennelly, J.K.G. Kramer, K. A. Beauchemin, C.S. Stanton, and J.J. Murphy. 2010. Effect of grain type and processing method on rumen fermentation and milk rumenic acid production. Animal 4:1425-1444.

Morales, R., A.P.S. Aguiar, I. Subiabre, and C.E. Realini. 2013. Beef acceptability and consumer expectations associated with production systems and marbling. Food Quality and Preferences 29:166-173.

Morales, R., C. Folch, S. Iraira, N. Teuber and C.E. Realini. 2012. Nutritional quality of beef produced in Chile form different production systems. Chilean Journal of Agricultural Research 72:80-86.

Pordomingo, A.J., T.P. García, and G. Volpi Lagreca. 2012. Effect of feeding treatment during the backgrounding phase of beef production from pasture on: II. Longissimus muscle proximate composition, cholesterol and fatty acids. Meat Science 90: 947-955.

Realini, C.E., S.K. Duckett, G.W. Brito, M. Dalla Rizza, and D. De Mattos 2004. Effect of pasture vs. concentrate feeding with or without antioxidants on carcass characteristics, fatty acid composition, and quality of Uruguayan beef. Meat Science 66:567-577.

Realini, C.E., Z. Kallas, M. Pérez-Juan, I. Gómez, J.L. Olleta, M.J. Beriain, P. Albertí, and C. Sañudo. 2014. Relative importance of cues underlying Spanish consumers' beef choice and segmentation, and consumer liking of beef enriched with n-3 and CLA fatty acids. Food Quality and Preference 33:74-85.

Rojas, C., A. Catrileo, and T. Grez. 2011. Evaluación productiva y económica del uso de grano entero de avena (Avena sativa L.) y lupino australiano (Lupinus angustifolius L.) en raciones de engorda invernal de vaquillas. Chilean Journal of Agricultural \& Animal Sciences 27:41-48.

Sadzawka, A., M. Carrasco, R. Demanet, H. Flores, R. Grez, M. Mora, and A. Neaman. 2007. Métodos de análisis de tejidos vegetales. Serie Actas Instituto de Investigaciones Agropecuarias. No. 40. Santiago, Chile.

Schor, A., M.E. Cossu, A. Picallo, J. Martínez Ferrer, J.J. Grigera Naón, and D. Colombatto. 2008. Nutritional and eating quality of Argentinian beef: A review. Meat Science 79:408-422.

Shewry, P.R. 2009. Wheat. Journal of Experimental Botany 60:1537-1553.

Teuber, N. 2009. Praderas permanentes en las zonas lecheras de Chile, Curvas de crecimiento, distribución y producción. Consorcio Lechero S.A. Osorno, Chile. 62 pp.

Woods, V.B., and A.M. Fearon. 2009. Dietary sources of unsaturated fatty acids for animals and their transfer into meat, milk and eggs: A review. Livestock Science 126:1-20.

Yang, A, M.J. Brewster, M.C. Lanari, and R.K. Tume. 2002. Effect of vitamin E supplementation on $\alpha$-tocopherol and $\beta$-carotene concentrations in tissues from pasture- and grain-fed cattle. 
Meat Science 60:35-40.

Zened, A, F. Enjalbert, M.C. Nicot, and A. TroegelerMeynadier. 2012. In vitro study of dietary fac- tors affecting the biohydrogenation shift from trans-11 to trans-10 fatty acids in the rumen of dairy cows. Animal 6:459-467. 